\title{
DIETARY SUPPLEMENTS THAT CONTAIN BIOTIN DO NOT INFLUENCE FLUORESCENCE THYROID-STIMULATING HORMONE VALUES WHEN SCREENING FOR CONGENITAL HYPOTHYROIDISM IN NEWBORNS
}

\section{SUPLEMENTY DIETY ZAWIERAJĄCE BIOTYNĘ NIE WPŁYWAJĄ NA STĘŻENIE FLUORESCENCYJNE TSH OKREŚLONE W PRZYPADKU WRODZONEJ NIEDOCZYNNOŚCI TARCZYCY W BADANIACH PRZESIEWOWYCH NOWORODKÓW}

\author{
Oana Roxana Oprea ${ }^{1(\mathrm{~A}, \mathrm{~B}, \mathrm{E}, \mathrm{F})}$, Stefan Valeriu Barbu ${ }^{1(\mathrm{~B}, \mathrm{C}, \mathrm{D}) \text {, }}$ \\ Minodora Dobreanu $^{1(\mathrm{~A}, \mathrm{E}, \mathrm{G})}$, Adina Hutanu $^{1(\mathrm{~B}, \mathrm{D})}$
}

${ }^{1}$ George Emil Palade University of Medicine, Pharmacy, Science, and Technology of Târgu Mureş, Romania

Authors' contribution

Wkład autorów:

A. Study design/planning

zaplanowanie badań

B. Data collection/entry

zebranie danych

C. Data analysis/statistics

D. Data interpretation

interpretacja danych

E. Preparation of manuscript

przygotowanie artykułu

F. Literature analysis/search

wyszukiwanie $\mathrm{i}$ analiza literatury

G. Funds collection

zebranie funduszy dane - analiza i statystyki

\section{Summary}

Background. Biotin levels may interfere with immunological tests that use biotin-streptavidin complexes. Although the recommended daily intake (RDI) of biotin is $30 \mu \mathrm{g}$, some dietary supplements that are available without prescription contain double or even tenfold the RDI. Material and methods. To asses if biotin levels influence thyroid-stimulating hormone (TSH) serum concentrations using two different methods (chemiluminescent assay [CLIA] and fluorescent immunoassay [FEIA]), 110 samples from newborns and 64 samples from pregnant women in the first trimester were collected. Participants completed a questionnaire regarding dietary supplement use. Biotin levels were determined using the ELISA technique.

Results. Biotin levels for newborns were $0.004-0.170 \mathrm{ng} / \mathrm{ml}$ and for pregnant women were $0.070-0.155 \mathrm{ng} / \mathrm{ml}$ (22 women were taking supplements containing from $30 \mu \mathrm{g}$ to $35 \mathrm{mg}$ of biotin). Biotin levels were below the value of $400 \mathrm{ng} / \mathrm{ml}$ stated by the manufacturer of the CLIA method to influence TSH levels. The FEIA manufacturer does not state the influence of biotin levels in the insert. Correlation tests results between TSH value and biotin were $r=-0.1$ for CLIA method and $\mathrm{r}=0.04$ for FEIA method.

Conclusions. According to our results, TSH values are not influenced by biotin levels even if the RDI was exceeded.

Keywords: dietary supplements, biotin, immunological tests

\section{Streszczenie}

Wprowadzenie. Poziomy biotyny mogą zakłócać testy immunologiczne wykorzystujące kompleksy biotyna-streptawidyna. Chociaż ZDS (zalecane dzienne spożycie) wynosi $30 \mu \mathrm{g}$, niektóre suplementy diety dostępne bez recepty zawierają podwójne lub nawet dziesięciokrotne wartości ZDS.

Materiał i metody. Zebrano 110 próbek od noworodków i 64 próbki od ciężarnych kobiet w pierwszym trymestrze ciąży, aby ocenić, czy poziomy biotyny mogą wpływać na stężenie TSH w surowicy przy dwóch różnych metodach (CLIA i FEIA). Wykorzystano też kwestionariusz dotyczący zastosowanego suplementu diety. Poziomy biotyny określono za pomocą techniki ELISA.

Wyniki. Poziom biotyny w przypadku noworodków znajdował się w przedziale 0,004-0,170 ng/ ml, a w przy padku kobiet ciężarnych: $0,070-0,155 \mathrm{ng} / \mathrm{ml}$ (22 kobiety przyjmowały suplementy diety zawierające od $30 \mu \mathrm{g}$ do $35 \mathrm{mg}$ biotyny). Poziom biotyny był poniżej wartości $400 \mathrm{ng} / \mathrm{ml}$ podanej przez producenta metody CLIA, aby mógł wpłynąć na poziomy TSH. Producent FEIA nie deklaruje takiego wpływu we wkładce. Wyniki testów korelacji pomiędzy wartością TSH a biotyną wynosiły: $\mathrm{r}=-0,1 \mathrm{w}$ metodzie CLIA i $\mathrm{r}=0,04 \mathrm{w}$ metodzie FEIA.

Wnioski. Zgodnie z wynikami, poziomy biotyny nie mają wpływu na stężenie TSH, nawet jeśli ZDS zostało przekroczone.

Figures: 1

References: 14

Submitted: 2020 Jan 13

Accepted: $2020 \mathrm{Feb} 3$
Słowa kluczowe: suplementy diety, biotyna, testy immunologiczne 


\section{Introduction}

Immunoassays are widely used in the clinical laboratory because they can be easily automated and have high precision and sensitivity. Although robust, some of these tests may be influenced by several factors that can lead to erroneous results [1]. In some cases, this may lead to increased or decreased values of the analyte and could consequently mask a pathology [2]. Alternatively, hormonal profiles may be modified in such a manner that another pathology could be suspected or misdiagnosed [3]. Sandwich immunoassays are commonly used for determining levels of large molecules such as thyroid-stimulating hormone (TSH), human chorionic gonadotropin (HCG), or other pituitary hormones. TSH is recognized by two different antibodies: one is bound with the solid phase used in the reaction and one is tagged with a signal molecule that will be measured (enzyme marked, chemiluminescent, or fluorescent substrate). The antibody bound to the solid phase (capture antibody) separates the antigen-antibody complexes, and this reaction is enhanced by biotin-streptavidin complexes. Biotin-streptavidin complexes are used by manufacturers due to their stability and lack of interference with the molecular proprieties of the substances. According to data from external quality control programs, $50 \%$ of all immunoassays for hormones used in France use biotin-streptavidin complexes [4].

Biotin is a soluble vitamin which is part of the B complex and is also referred to as vitamin B7 or vitamin $\mathrm{H}$. Biotin is a coenzyme for carboxyl transfer in five different carboxylases. A daily intake of $30 \mu \mathrm{g}$ is recommended for healthy adults [5]. Some supplements that contain biotin may influence immunoassays that use biotinylated antibodies or streptavidin [6], although others may contain a low dose of biotin that is unlikely to influence immunoassays [7, 8]. Normal serum concentrations of biotin are $0.1-0.8 \mathrm{ng} / \mathrm{ml}$. Biotin is rapidly absorbed and reaches peak serum concentration 1-2 hours after ingestion. Doses of about $10 \mathrm{mg}$ can lead to concentrations of $55-140 \mathrm{ng} / \mathrm{ml}$, while doses of $100 \mathrm{mg}$ can lead to concentrations of 375-450 ng/ml. Continuous administration of biotin can lead to the accumulation of biotin in serum and may double the initial value [9]. Biotin is used in supplements for pregnant women and for products that claim to help hair and skin health, and is available without a prescription. Considering that the food supplement market has expanded in the EU, although advertising is regulated [10], some accumulation of biotin is expected in patients who consume supplements containing a high dose of biotin. The aim of this study was to asses biotin influence on TSH values determined with fluorescent immunoassay (FEIR), a method that is used in a newborn screening program for early detection of congenital hypothyroidism (CH), and on TSH values determined by chemiluminescent immunoassay (CLIA).

\section{Material and methods}

The study was approved by the Ethics Committee of the Târgu Mureş Emergency County Hospital. After written consent was obtained from the mothers, a $7 \mathrm{ml}$ tube with no additives was used to collect blood samples from 122 newborns. Samples were centrifuged for 20 minutes at $4000 \mathrm{rpm}$ and the serum obtained was stored at $-80^{\circ} \mathrm{C}$ until TSH and biotin levels were determined. On the same day, from each newborn a sample of whole blood was collected on dried blood spots (DBS) on filter paper grading 903 (Whatman 903, Sigma Aldrich), according to regulations from the national screening program.

To establish biotin influence on TSH values determined by the CLIA method in adults, blood samples from 64 women in the first 14 weeks of pregnancy were collected. At the date of collection, participants completed a questionnaire concerning any dietary supplements that were prescribed or that had been taken without prescription from a physician. $7 \mathrm{ml}$ of blood was collected and the serum was stored at $-80^{\circ} \mathrm{C}$ until $\mathrm{TSH}$ and biotin values were determined.

Serum TSH values were determined with CLIA using the Immulite 2000 instrument (Siemens, Germany) with Siemens reagents. Analytical sensitivity of third-generation Siemens TSH is $0.004 \mu \mathrm{UI} / \mathrm{ml}$, inter-assay precision is $5.1 \%$, and analytical recovery is $100 \%$. For newborns, TSH was also determined using DBS samples and the FEIA method (LabSystems Diagnostics Oy, Norway). The sensitivity of the TSH FEIA kit is 0.9 mUI/L blood, interassay imprecision (CV\%) is 8.8\%, and analytical recovery is 81\%. CLIA manufacturer states that tests are not influenced by biotin below $400 \mathrm{ng} / \mathrm{ml}$ and FEIA manufacturer does not state such in interference.

Biotin concentrations in serum were determined with enzyme-linked immunosorbent assay (ELISA) kits from Cusabio (USA) with a direct competitive inhibition immunoassay. A competitive inhibition reaction was initiated between biotin from samples and horseradish peroxidase (HRP) conjugated biotin from the kit, in avidin pre-coated ELISA wells. After the substrate was added, a colour reaction developed according to the amount of biotin conjugated in the initial step. The ELISA kit had a detection range of $0.012-0.020 \mathrm{ng} / \mathrm{ml}$ and a sensitivity of $0.004 \mathrm{ng} / \mathrm{ml}$. A four-parameter logistic standard curve with 6 calibrator values was used.

Data from questionnaires and serum TSH and biotin levels were tabulated on Excel spreadsheets and statistically analyzed using MedCalc software version 14.8.1. The Kolmogorov-Smirnov test was used to verify 
normal distribution. In order to evaluate the influence of biotin levels on TSH values, correlation coefficient tests were performed. A p-value $<0.05$ was considered as statistically significant.

\section{Results}

Of 122 samples that were collected from newborns, biotin was determined from 110 specimens; for the remaining 12, serum was insufficiently collected. Values obtained from newborns were $0.004-0.170 \mathrm{ng} / \mathrm{ml}$, with a parametric distribution. Of the 64 questioned women, 22 had taken three different type of supplements that contained biotin (in 15 cases the biotin concentration was $35 \mathrm{mg}$, while in the remaining 7 cases the concentration of biotin in two types of supplements was $60 \mu \mathrm{g}$ ), 17 had taken supplements that contained only folic acid, and 25 declared that they did not take any supplements. The most commonly used supplement contained 10 times the recommended daily intake (RDI) of biotin, which is $30 \mu \mathrm{g}$, while the other two contained two times the RDI. Biotin serum levels from pregnant women were 0.070-0.155 ng/ml.

TSH values in newborns using both techniques (FEIA and CLIA) were tabulated on Excel spreadsheets. Values obtained with the FEIA technique from DBS were 1.24-9.01 mUI/L, with a non-parametric distribution. To compare values from whole blood with values from serum, values obtained in serum were multiplied by 0.45 . The value of 0.45 was used because it is considered a normal value for haematocrit in newborns; this value also used when reporting External Quality Assurance results and is recommended by the manufacturer of the FEIA kit.

Values obtained in serum with the CLIA technique were $0.20-11.43 \mu \mathrm{UI} / \mathrm{L}$ after the transformation was applied. TSH values in serum also presented a non-parametric distribution. Data from patients who did not have TSH values determined using both methods, and a biotin serum level, were excluded from the analysis.

\section{A)}

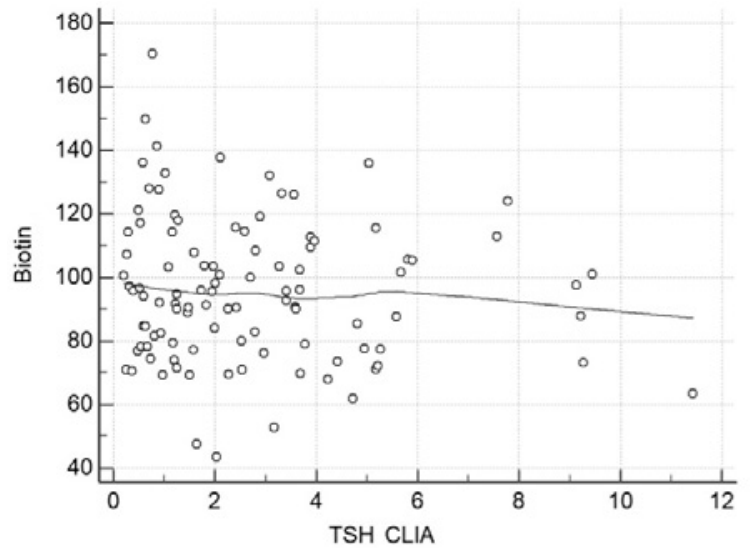

B)

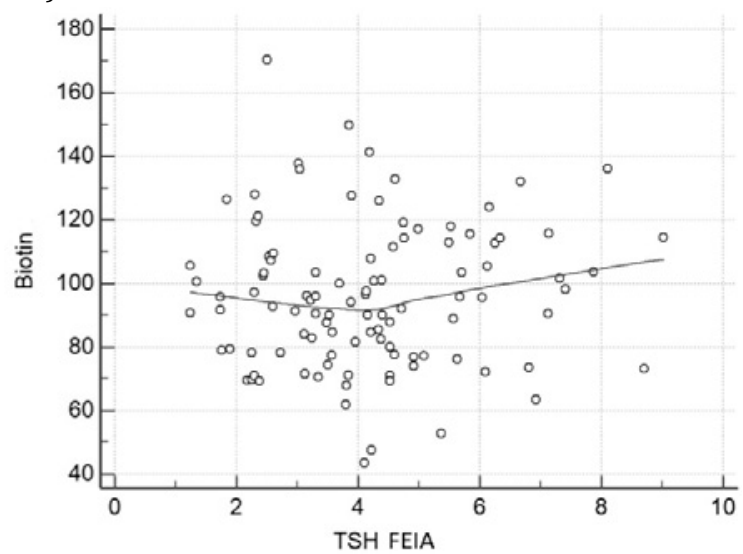

Figure 1. Correlation tests for serum biotin and TSH levels using CLIA ( $\mathrm{r}=-0.1)$ - A; correlation between biotin levels and TSH using FEIA $(r=0.04)-B$

Correlation tests between TSH values from serum and whole blood and serum biotin levels are shown in Figure1. Results obtained using the CLIA method $(\mathrm{p}=0.27)$ showed that there was no correlation between serum TSH values and biotin level. For the FEIA method, statistical tests showed no correlation between whole blood TSH values and biotin levels in patient serum $(\mathrm{p}=0.62)$.

\section{Discussion}

Biotin may influence different types of immunoassays (both competitive and sandwich) in different ways, leading to a false increase or decrease in the concentration of a specific analyte. In a study on the influence of biotin on hormone and vitamin levels, Piketty et al. listed 5 cases in which TSH values were lower than reference levels, due to biotin interference [1]. Jenkins et al. published a review on the influence of biotin on immunoassays and evaluated data provided by manufacturers. Siemens states that biotin influences TSH values only above the value of $400 \mu \mathrm{g} / \mathrm{L}$ in serum [11]. Li et al. showed that in the case of 6 healthy adults who were taking $10 \mathrm{mg}$ of biotin/day for 7 days, an influence was observed in 9 out of 23 immunoassays evaluated. The authors used immunoassays from 3 different manufacturers (Roche, Siemens, and Orthoclinical Diagnostic). The influence of biotin was assessed using in vivo studies, in which certain amounts of biotin were administered, and in vitro by adding biotin to patient samples. Effects on TSH values were dependent on dosage and manufacturer; $300 \mathrm{ng} /$ $\mathrm{ml}$ of biotin supplementation led to a 7-10\% increase in TSH using Siemens Vista, while only 6-15 $\mathrm{ng} / \mathrm{ml}$ of biotin 
supplementation was necessary to produce the same effect on Roche Elecsys and Vitros methods [12]. In our study none of the patients had such high levels of biotin in serum and no biotin was added in patients samples.

In a published document from the Food and Drug Administration (FDA), it is recommended that manufacturers should investigate the influence of biotin up to $1200 \mathrm{ng} / \mathrm{ml}$, and determine the smallest concentration of biotin that changes the results significantly (this threshold for change was set at 10\%) [13]. In a document published by American Association of Clinical Chemistry (AACC) regarding biotin influence on immunoassays, 20 studies on biotin influence were listed. Most of these studies referred to influences on thyroid hormones, and the most common consequences were a misdiagnosis of Graves' disease. Of the 20 studies reported, only 2 studies referred to serum thyroid hormone levels in newborns. In these two cases, both newborns were misdiagnosed with Graves' disease and one was taking $10 \mathrm{mg}$ of biotin as a prophylactic treatment for organic academia [14]. Even if such cases are rare, such treatments should be known by laboratory staff in order to properly evaluate patient's results.

\section{Conclusions}

In the present study, we did not find any significant correlation between biotin levels in serum and TSH levels measured with CLIA (Siemens) and FEIA (LabSystems Diagnostics Oy). Values of biotin measured in newborns were below the value stated by the manufacturer (Siemens) to produce analytical interference in serum thyroid hormone assessment. Regarding the FEIA method, the manufacturer does not state the possible influence of biotin on TSH results. This may be due to the lack or insufficient investigation of this aspect. As for biotin serum levels obtained in pregnant women, these were below the values stated by Siemens, irrespective of whether or not they were taking supplements that contain biotin.

\section{References:}

1. Piketty ML, Polak M, Flechtner I, Gonzales-Briceno L, Souberbielle J-C. False biochemical diagnosis of hyperthyroidism in streptavidin-biotin-based immunoassays: the problem of biotin intake and related interferences. Clin Chem Lab Med. 2017; 55(6): 780-788. https://doi.org/10.1515/cclm-2016-0606

2. Wijeratne NG, Doery JC, Lu ZX. Positive and negative interference in immunoassays following biotin ingestion: a pharmacokinetic study. Pathology. 2012; 44(7): 674-675. https://doi.org/10.1097/PAT.0b013e32835a3c17

3. Barbesino G. Misdiagnosis of Graves' disease with apparent severe hyperthyroidism in a patient taking biotin megadoses. Thyroid. 2016; 26(6): 860-863. https://doi.org/10.1089/thy.2015.0664

4. Faix JD. Principles and pitfalls of free hormone measurements. Best Pract Res Clin Endocrinol Metab. 2013; 27(5): 631-645. https://doi.org/10.1016/j.beem.2013.06.007

5. National Research Council. Dietary reference intakes for Thiamin, Riboflavin, Niacin, Vitamin B6, Folate, Vitamin B12, Pantothenic acid, Biotin, and Choline. National Academy of Sciences. Washington, DC: National Academy Press; 1998: p. 374-389.

6. www.elevit.ro [Internet]. Bucharest: Bayer Romania. [Insert of Elevit] [cited 2019 Aug]. Available from: https://elevit.ro/ro/wp-content/uploads/2017/02/Elevit-3.pdf (in Romanian).

7. www.femibion.ro [Internet]. Bucharest: Dr. Reddy's Laboratories România SRL. [Insert of Femibion 2] [cited 2019 Aug]. Available from: https://www.femibion.ro/femibion2/(in Romanian).

8. www.sunwavepharma.com [Internet]. Bucharest: Sediul Sun Wave Pharma. [Insert of Femosun] [cited August 2019]. Available from: https://sunwavepharma.com/en/produse/uro-gineco/femosun/ (in Romanian).

9. Grimsey P, Frey N, Bendig G, Zitzler J, Lorenz O, Kasapic D, et al. Population pharmacokinetics of exogenous biotin and the relationship between biotin serum levels and in vitro immunoassay interference. International Journal of Pharmacokinetics. 2017; 2(4): 247-256. https://doi.org/10.4155/ipk-2017-0013

10. Crisan O. Health claims in food supplements advertising. Farmacia. 2012; 60(1): 138-142.

11. Jenkins Colon P, Greene DN. Biotin interference in clinical immunoassays. JALM. 2018; $2(6)$ : $941-951$. https://doi.org/10.1373/jalm.2017.024257

12. Li D, Radulescu A, Shrestha RT, Root M, Karger AB, Killeen AA, et al. Association of biotin ingestion with performance of hormone and nonhormone assays in healthy adults. JAMA. 2017; 318(12): 1150-1160. https://doi.org/10.1001/jama.2017.13705

13. www.fda.gov [Internet]. Silver Spring: U.S. Food and Drug Administration. The FDA warns that biotin may interfere with lab tests: FDA safety communication [cited 2019 Aug]. Available from:

https://www.fda.gov/medicaldevices/safety/alertsandnotices/ucm586505.html

14. Li D, Ferguson A, Cervinski MA, Lynch KA, Kyle PB. AACC guidance document on biotin interference in laboratory tests. The Journal of Applied Laboratory Medicine. 2020; jfz010.

https://doi.org/10.1093/jalm/jfz010 